\title{
Penerapan Sistem Informasi Pendataan Penerima Dana Program Keluarga Harapan pada Gampong Beurawe Kecamatan Kuta Alam berbasis Web GIS
}

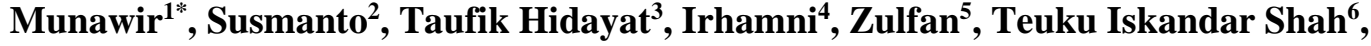 \\ Nadia Fachriana ${ }^{7}$ \\ 1,2,3,5,6,7 Program Studi Teknik Komputer, Fakultas Teknik, Universitas Serambi Mekkah, Banda Aceh \\ ${ }^{4}$ Program Studi Teknik Kimia, Fakultas Teknik, Universitas Serambi Mekkah, Banda Aceh \\ *Koresponden email: irhamni@ serambimekkah.ac.id
}

Diterima: 1 Agustus 2021

Disetujui: 24 Agustus 2021

\begin{abstract}
Administratively, Gampong Beurawe is one of the villages in Kuta Alam District, Banda Aceh City. The Department of Social Affairs is in charge of collecting data and providing assistance to people in need of social welfare services. Data collection is done manually in the form of archives and files, this causes inefficiencies in space, security, time and costs. The Social Service has difficulties in conveying information on the Family Hope Program (PKH) which includes data on poor households, education data and health data, to the wider community and related parties, causing data information to be unclear. So we need an automatic data collection system to help collect data on the hopeful family program in Gampong Beurawe, Kuta Alam District. In the geographic information system itself, there are two important elements, namely Geographical Data which is used as a reference for attribute data. The design of the map that will be displayed in this application uses map info and google maps. This PKH acceptance mapping information system in Beurawe Village, Kuta Alam District, Banda Aceh City is to assist the Social Service, especially the social assistance and security department in the storage and delivery of information data (PKH) so that it can provide clear information about the program. Data information system in the form of maps, graphs and tables.
\end{abstract}

Keywords: PKH, Mapping, Beurawe Village, MySqL, Web Based

\begin{abstract}
Abstrak
Secara Administratif Gampong Beurawe merupakan salah satu Gampong di Kecamatan Kuta Alam Kota Banda Aceh. Dinas Sosial bertugas mendata dan memberikan bantuan kepada masyarakat yang membutuhkan pelayanan kesejahteraan sosial. Pendataan dilakukan secara manual dalam bentuk arsip dan berkas, hal ini menimbulkan ketidak efisiensi tempat, keamanan, waktu dan biaya. Dinas Sosial kesulitan dalam menyampaikan informasi program keluarga harapan (PKH) yang meliputi data rumah tangga miskin data pendidikan dan data kesehatan kepada masyarakat luas serta pihak-pihak terkait sehingga menyebabkan ketidak jelasan informasi data. Sehingga diperlukan suatu sistem pendataan otomatis untuk membantu pendataan program keluarga harapan di Gampong Beurawe Kecamatan Kuta Alam. Di dalam sistem informasi geografis sendiri terdapat dua elemen penting yaitu Data Geografis yang digunakan sebagai acuan untuk data atribut. Perancangan peta yang akan ditampilkan dalam aplikasi ini menggunakan map info dan google maps. Sistem informasi pemetaan penerimaan PKH pada Gampong Beurawe Kecamatan Kuta Alam kota Banda Aceh ini untuk membantu Dinas Sosial khususnya bagian bidang bantuan dan jaminan sosial di dalam penyimpanan dan penyampaian data informasi (PKH) sehingga dapat memberikan informasi data tentang program dengan jelas. Sistem informasi data berupa peta, grafik dan tabel.
\end{abstract}

Kata Kunci: $P K H$, Pemetaan, Desa Beurawe, MySqL, Berbasis Web

\section{Pendahuluan}

Secara administratif Gampong Beurawe merupakan salah satu gampong dari sebelas desa yang terdapat di Kecamatan Kuta Alam Kota Banda Aceh [1]. Secara geografis, Gampong Beurawe memiliki posisi yang strategis di Kota Banda Aceh karena memiliki akses yang cukup luas dan dapat dicapai dari berbagai tempat di Kota Banda Aceh [8]. Jumlah penduduk Gampong Beurawe mencapai 5948 jiwa dengan mata pencaharian masyarakat umumnya sebagai wiraswasta dan petani. Di Beurawe terdapat berbagai macam potensi diantaranya UMKM, tempat wisata serta pertanian [15]. Banyaknya penduduk yang tersebar 
di desa Beurawe menimbulkan kendala bagi pemerintah untuk memantau atau memetakan keadaan masyarakat di Beurawe, khususnya masyarakat yang sudah mendapat bantuan Sosial untuk pengentasan Kemiskinan serta pengusulan bantuan di desa Beurawe. Data pada tahun 2020 di Gampong Beurawe sebanyak 56 kepala keluarga masyarakat mendapatkan bantuan sosial, dimana dalam pengecekan perkembangan bantuan dan pengusulan bantuan yang membutuhkan waktu selama 1 bulan dan pemberian bantuan yang belum akurat ke masyarakat yang kurang mampu, menyimpan data dengan menggunakan dokumen hardcopy sehingga memakan banyak tempat dan rentan akan kehilangan data yang menyebabkan kerugian dan kurang efisien [2]. Adapun tujuan dilakukannya pemetaan dan pemantauan yaitu untuk memudahkan perangkat desa memberikan bantuan berupa program - program bantuan seperti bantuan kesehatan, bantuan hewan ternak dan lain sebagainya [4]. Selain itu pemantauan yang dilakukan terhadap penduduk yang mendapatkan bantuan sosial masih secara manual yaitu dengan melakukan pendataan ke masing - masing rumah, khususnya yang mendapat bantuan sosial [11]. Berdasarkan dari permasalahan seperti yang diuraikan di atas penulis membuat Sistem Informasi Pemetaan Penerima PKH pada Desa Beurawe Kecamatan Kuta Alam Kota Banda Aceh sehingga dapat memudahkan petugas dalam pelayanan masyarakat di desa Beurawe.

\section{Metode Penelitian}

Metode penelitian ini, dengan menggunakan metode waterfall yang merupakan model yang melakukan pendekatan pada perkembangan perangkat lunak secara sistematik dan sekuensial yang artinya kegiatan pada model ini dilakukan berdasarkan panduan proses mulai dari komunikasi kepada masyarakat sampai dengan aktivitas setelah masalah dipahami secara lengkap dan berjalan stabil sampai selesai [13]. Berikut metode penelitian Sistem Informasi pemetaan penerimaan PKH pada Desa Beurawe Kecamatan Kuta Alam Kota Banda Aceh.

\subsection{Analisis Masalah}

Mengidentifikasi masalah merupakan langkah pertama yang dilakukan dalam tahap analisis sistem. Masalah dapat didefinisikan sebagai suatu pertanyaan yang diinginkan untuk dipecahkan. Masalah inilah yang menyebabkan sasaran dari sistem tidak dapat dicapai [3]. Oleh karena itu langkah pertama yang harus dilakukan pada tahap ini adalah mengidentifikasi terlebih dahulu masalah yang terjadi (identify).

\subsection{Analisis Sistem}

Prosedur merupakan urutan kegiatan yang tepat dari tahapan-tahapan yang menerangkan mengenai proses yang sedang dikerjakan, siapa yang mengerjakan proses tersebut, bagaimana proses tersebut dapat dikerjakan dan dokumen apa saja yang terlibat [4].

\subsection{Prosedur Sistem Berjalan}

Sistem yang berjalan saat ini dalam proses pendataan penerima PKH pada Gampong Beurawe, Kuta Alam Kota Banda Aceh masih melakukan secara menual yaitu petugas gampong mendata setiap penerima PKH dan dimasukkan ke dalam data excel. Untuk mengetahui aliran proses sistem berjalan, maka akan digambarkan dalam bentuk flowmap seperti Gambar 1.

Berdasarkan gambar di samping tersebut dapat dijelaskan bahwa penerima PKH membawa kartu identitas supaya bisa diinput oleh petugas ke dalam Microsoft Excel, kemudian data itu dijadikan sebagai laporan dan rekapan serta selanjutnya di serahkan kepada kepala desa. 


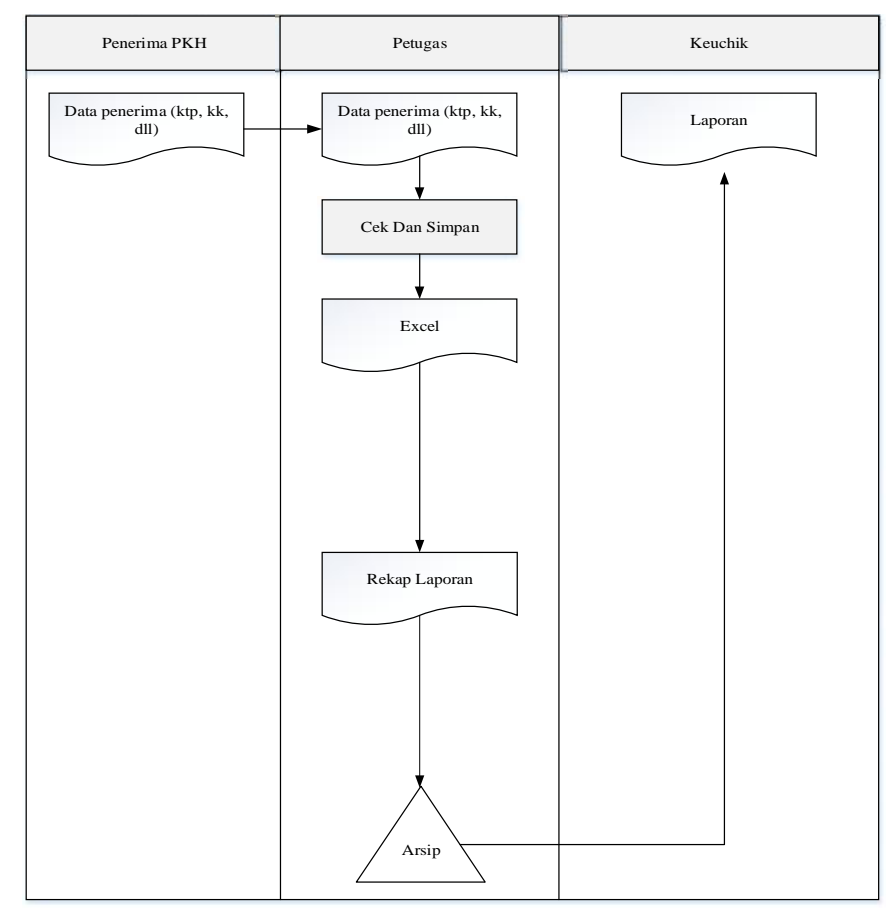

Gambar 1. Prosedur sistem berjalan

\subsection{Prosedur Sistem Usulan}

Selanjutnya akan diuraikan mengenai sistem yang akan diusulkan secara keseluruhan. Flowmap akan menjelaskan tentang siapa-siapa saja yang terlibat dalam sistem [5]. Sistem ini akan memanfaatkan sistem informasi untuk mendata penerima PKH dan terkoneksi dengan google maps, jadi pada saat butuh data penerima $\mathrm{PKH}$, jadi selain ada kode penerima sebagai primary, maka alamatnya langsung terkoneksi gmaps sesuai koordinat sehingga dengan adanya sistem usulan ini dapat kita lihat pada Flowmap sistem usulan sebagaimana yang di tampilkan pada Gambar 2.

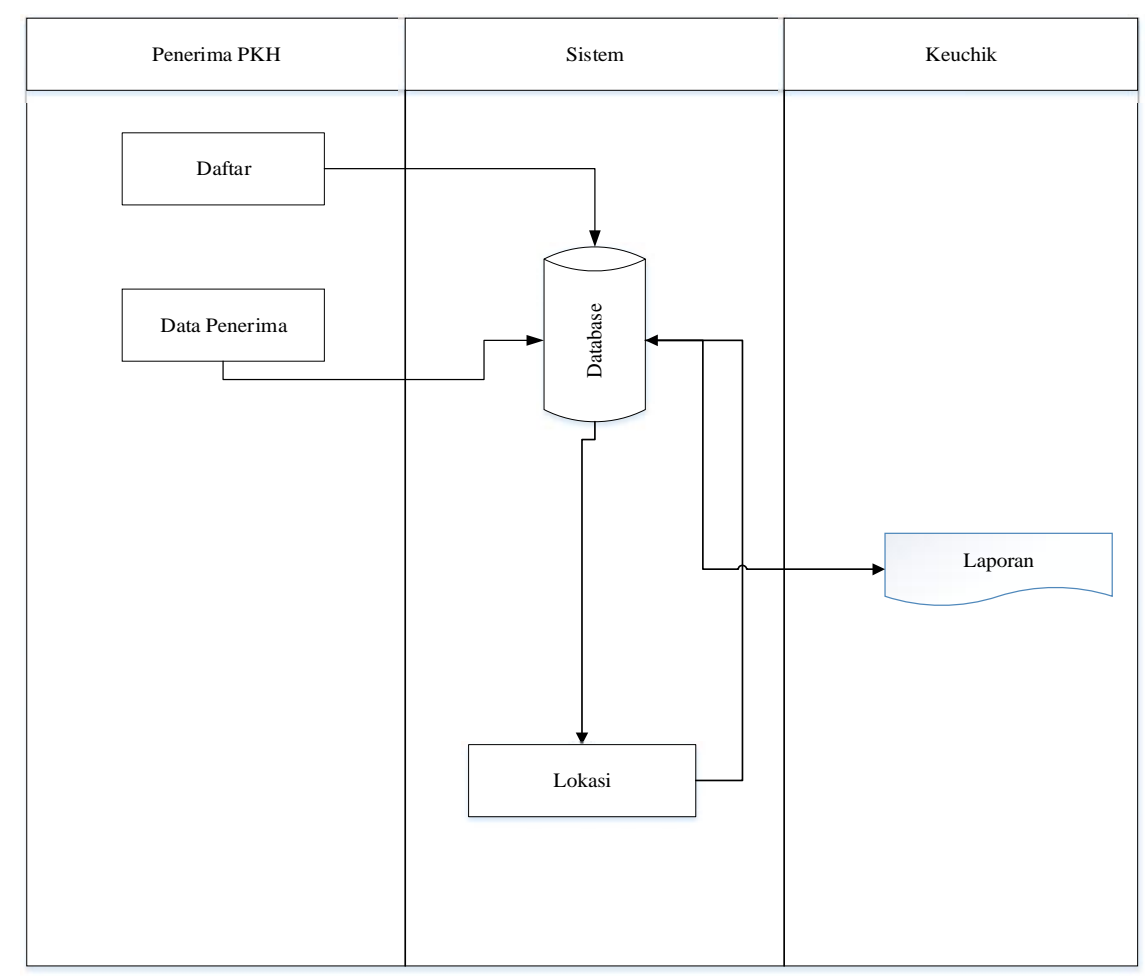

Gambar 2. Prosedur sistem usulan 


\subsection{Entity Relationsip Diagram}

Berdasarkan hasil analisis, didapat data yang akan digunakan dalam proses perancangan sistem informasi pemetaan penerima PKH Gampong Beurawe Kuta Alam Kota Banda Aceh agar petugas bisa mendata dengan koordinat setiap alamat dari penerima PKH sehingga mudah dipetakan. Kemudian dari data yang telah diperoleh, dibangun sebuah desain basis data dengan menggunakan tool Entity Relational Diagram (ERD) seperti pada Gambar 3.

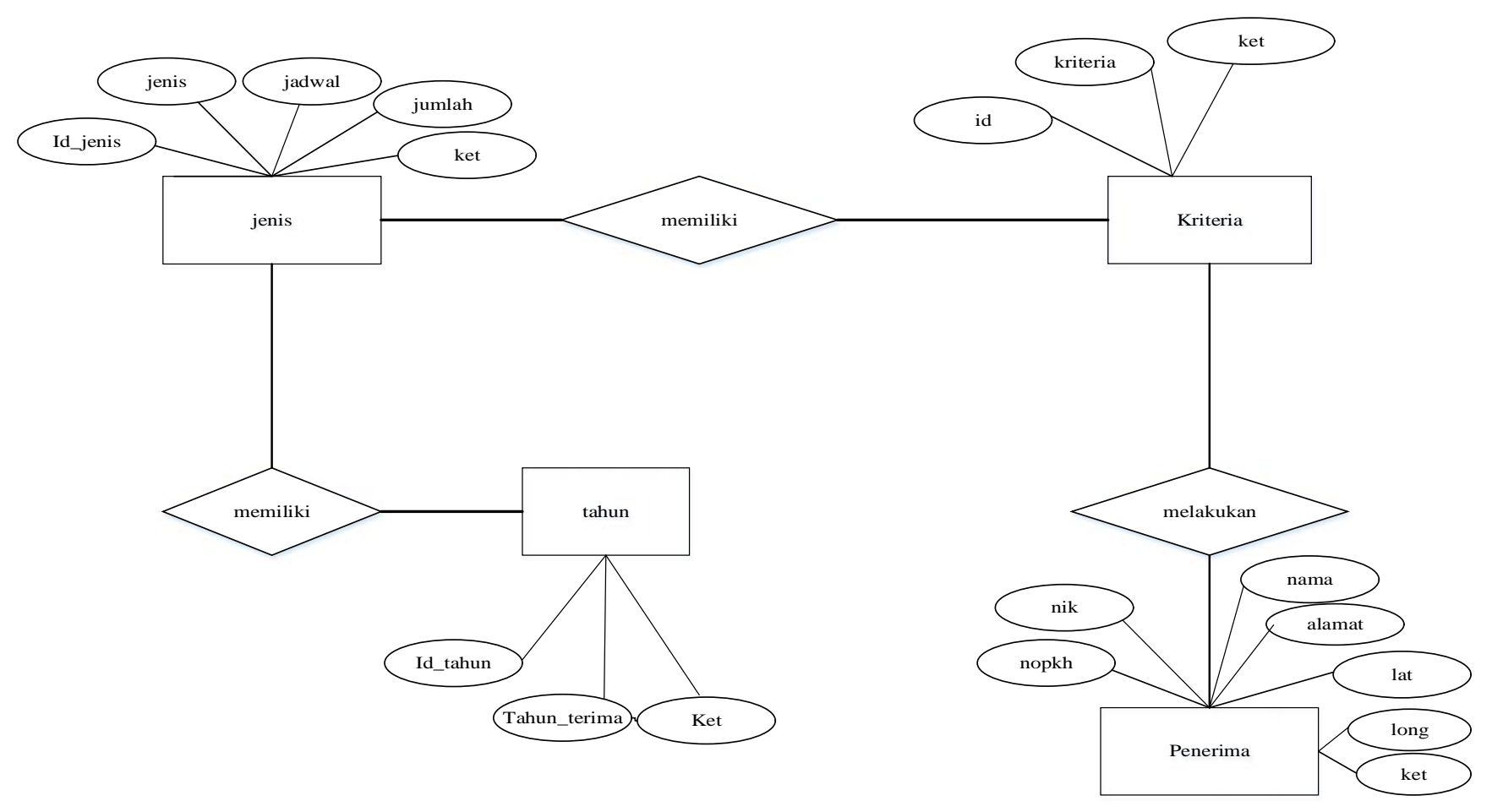

Gambar 3. Entity Relationsip Diagram (ERD)

Gambar 3 menjelaskan bahwa ERD diperoleh dari hasil analisis dan keterhubungan entitas satu ke entitas yang lain. Kemudian selain entitas dapat dijelaskan juga bahwa dalam pembuatan ERD maka diperlukan entitas dan atribut serta relasi yang menghubungkan pada setiap entitas yang ada.

\subsection{Rancangan Sistem}

Pada tahap rancangan akan diuraikan satu persatu yang dimulai dengan diagram konteks, kemudian diagram berjenjang, selanjutnya perancangan level 1, level 2 dan level 3 . Untuk lebih jelasnya tahap perancangan akan diuraikan sebagai berikut.

Diagram konteks merupakan alat-alat untuk struktur analisis. Pendekatan terstruktur ini mencoba untuk menggambarkan sistem secara garis besar atau keseluruhan. Dalam penggambaran ini, sistem dianggap sebagai sebuah objek yang tidak dijelaskan secara rinci, karena yang ditekankan adalah interaksi sistem dengan lingkungan yang mengaksesnya. Hubungan entitas yang mempengaruhi langsung yang akan dibuat untuk lebih jelasnya dapat dilihat pada Gambar 4. 


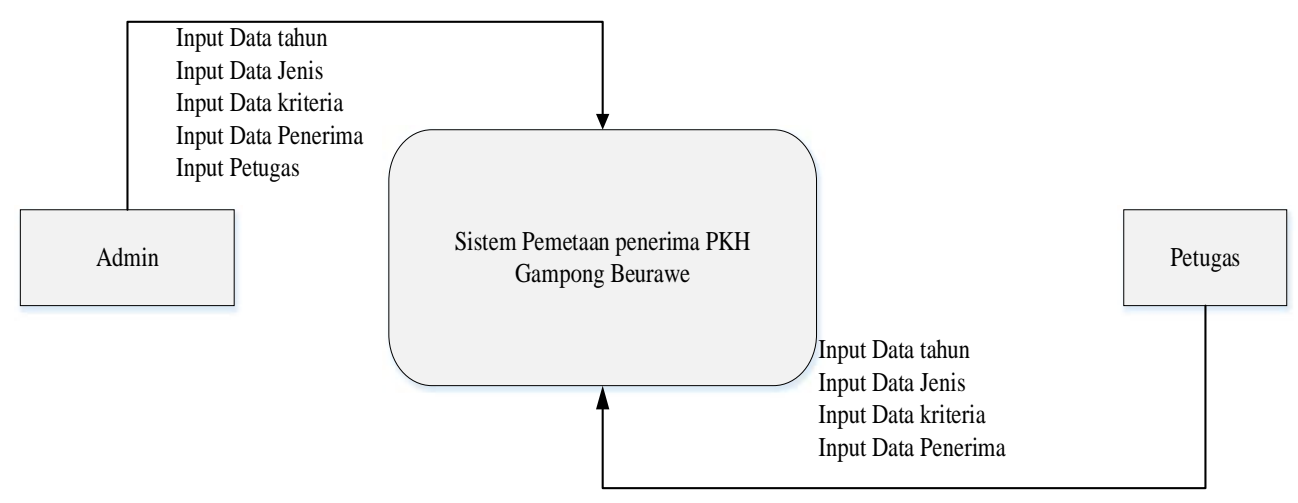

Gambar 4. Diagram konteks

Gambar 4 menjelaskan bahwa diagram konteks tersebut adalah sistem keseluruhan secara global. Dimana admin menginput terlebih dahulu data tahun anggaran, data jenis, data kriteria, dan data penerima serta data petugas. Berikut akan dijelaskan diagram berjenjang yang menjelaskan tentang turunan dari pada diagram kontek. Pada diagram berjenjang ini memiliki tiga level yaitu level 0, level 1, level 2 sebagaimana yang akan ditampilkan pada Gambar 5.

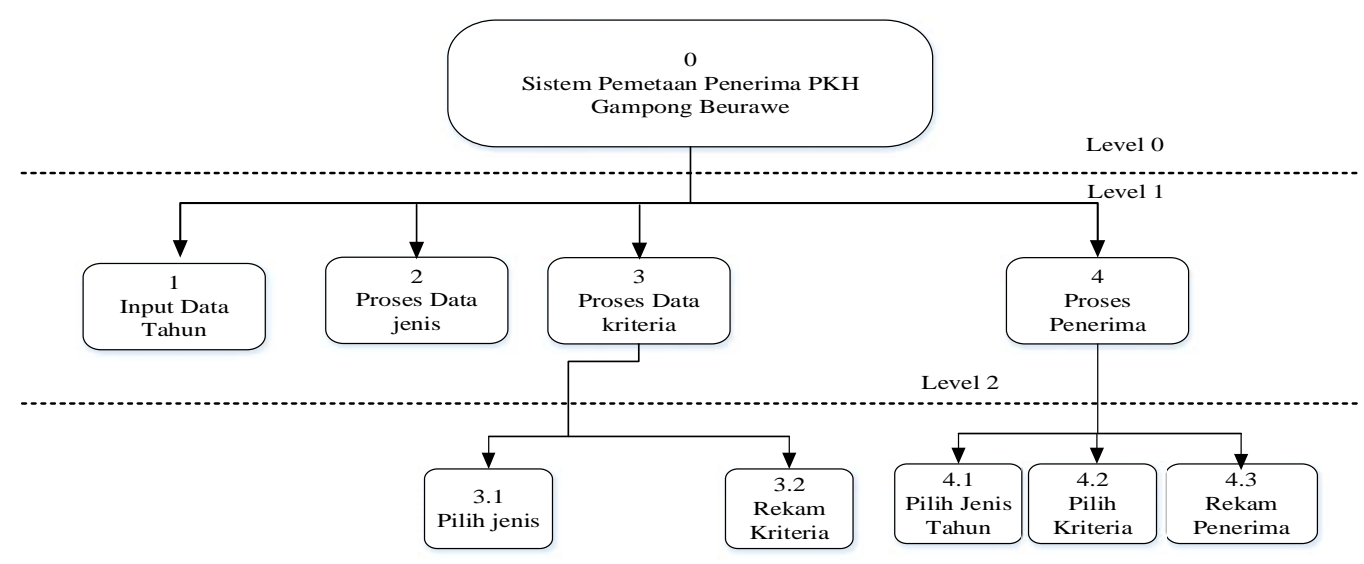

Gambar 5. Bagan berjenjang

\subsection{Data Flow Diagram (DFD) Level 1}

Selanjutnya akan di turunkan dari diagram berjenjang menjadi level 1 . Pada level 1 ini yang menjelaskan tentang proses yang dimulai dari penambahan data tahun, jenis, kriteria, dan penerima. Untuk lebih lanjutnya dapat dilihat pada Gambar 6. 


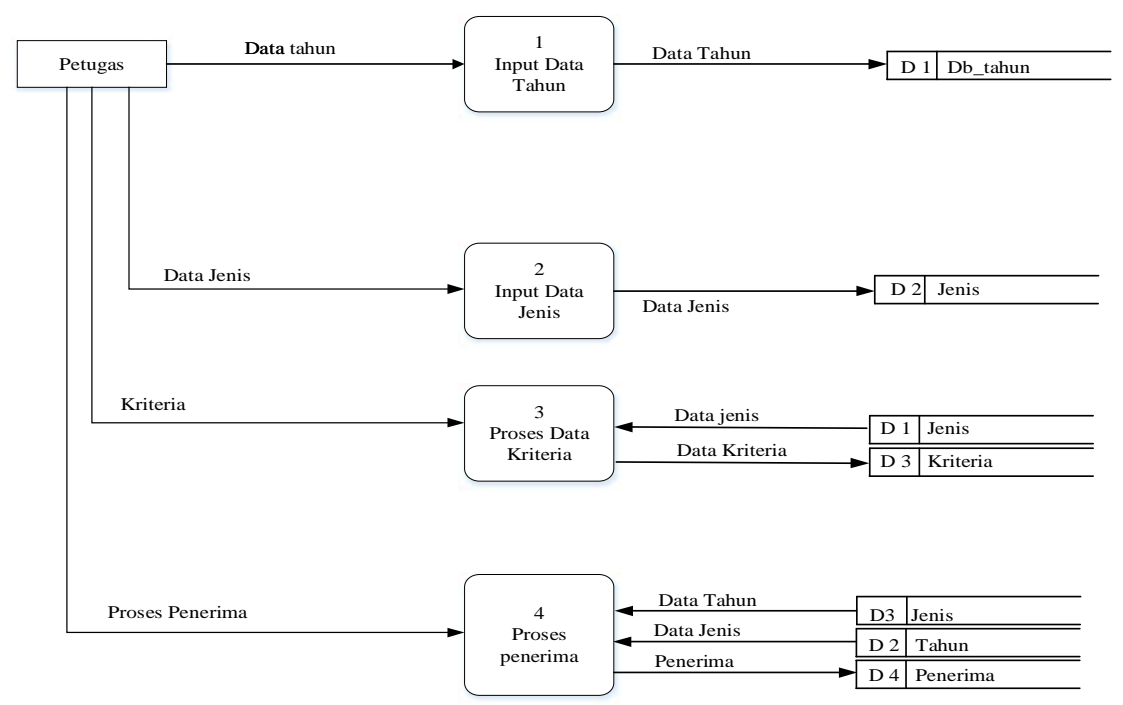

Gambar 6. DFD Level 1

Pada Gambar 6 adalah proses untuk penambahan data pemetaan PKH daerah Gampong Beurawe Kota Banda Aceh. Sehingga dapat menghasilkan sistem penerima PKH pada Gampong Beurawe.

\subsection{Rancangan Database}

Tabel 1 adalah tabel untuk admin atau user yang menggunakan secara langsung sistem yang akan dibangun. Pada tabel ini yang terdiri dari username, password, nama lengkap, level user dan blokir. Tabel ini memiliki lima buah kolom. Pada kolom pertama berisi nomor urut data, kemudian kolom kedua berisi tentang nama filed, kolom ketiga berisi tantang type data yang digunakan, kolom empat untuk menentukan panjang karakter, dan kolom yang kelima adalah keterangan dari field yang digunakan.

Tabel 1. User

\begin{tabular}{cllll}
\hline No. & Nama Field & Type & Size & Keterangan \\
\hline 1. & Kduser & Int & 11 & PK \\
2. & nama & Varchar & 30 & \\
3. & Password & Varchar & 30 & \\
4. & Level & Varchar & 30 & \\
5. & status & Varchar & 30 & \\
\hline
\end{tabular}

Tabel 1 berfungsi untuk membuat login kepada administrator, petugas dan staff barulah admin bisa menginput data - data yang dibutuhkan ke dalam sistem. Selanjutnya tabel Jenis admin yang berfungsi untuk menyimpan data jenis penerima PKH yang akan ditambahkan. Pada tabel ini digunakan oleh admin yang berhak memegang sistem. Form ini juga memiliki lima buah kolom yang diawali dengan kode data jenis datang, kemudian nama field, type data, size dan keterangan yang kesemuanya digunakan untuk menambahkan data jenis datang seperti yang ditampilkan pada Tabel 2.

Tabel 2. Jenis profil gampong

\begin{tabular}{clccc}
\hline No. & Nama Field & Type & Size & Keterangan \\
\hline 1. & kdedit & Int & 11 & PK \\
2. & judul & Varchar & 25 & \\
3. & Ket & Varchar & 30 & \\
\hline
\end{tabular}

Pada Tabel 2 dijelaskan mengenai data edit. Tabel ini juga memiliki tiga buah kolom yang diawali nomor urut data, nama field, type data, size dan keterangan. Tabel inilah yang digunakan oleh admin tempat menyimpan data profil gampong setelah diinput kedalam program. 
Tabel 3. Data tahun

\begin{tabular}{|c|c|c|c|c|}
\hline No. & Nama Field & Type & Size & Keterangan \\
\hline 1. & Kdtahun & Varchar & 10 & PK \\
\hline 2. & tahun & Varchar & 50 & \\
\hline 3. & Ket & Varchar & 50 & \\
\hline
\end{tabular}

Kemudian Tabel 4 ini berfungsi untuk tempat penyimpanan data tahun, tabel ini terdiri dari tiga buah kolom dan kolom yang pertama adalah nomor urut data yang digunakan, kedua nama field, type data, size dan keterangan yang kesemuanya digunakan untuk mengelola data tahun.

Tabel 4. Jenis bantuan

\begin{tabular}{clccc}
\hline No. & \multicolumn{1}{c}{ Nama Field } & Type & Size & Keterangan \\
\hline 1. & Kode_jenis & Varchar & 20 & PK \\
2. & jenis & Varchar & 25 & \\
3. & jadwal & Varchar & 30 & \\
4. & jumlah & Varchar & 30 & \\
5. & Keterangan & Varchar & 30 & \\
\hline
\end{tabular}

Kemudian dibawah ini akan ditampilkan Tabel 5 yang menjelaskan tentang data jenis bantuan. Tabel ini yang berfungsi dalam pengelolaan data jenis bantuan dan memiliki lima buah kolom yang di awali kolom nomor urut, kemudian nama field, type data, size dan keterangan. Tabel ini yang digunakan tempat penyimpanan data bantuan.

Tabel 5. Kriteria

\begin{tabular}{clccc}
\hline No. & \multicolumn{1}{c}{ Nama Field } & Type & Size & Keterangan \\
\hline 1. & kriteria & Varchar & 20 & PK \\
2. & jenis & Varchar & 20 & \\
3. & Keterangan & Varchar & 50 & \\
4. & Alamatawal & Varchar & 50 & \\
5. & Alamatdomisili & Varchar & 50 & FK \\
6. & Kdjenis & Varchar & 11 & FK \\
7. & Kddesa & Varchar & 11 & FK \\
8. & Longitute & Varchar & 11 & \\
9. & Langitute & Varchar & 50 & \\
\hline
\end{tabular}

\section{Hasil dan Pembahasan}

\subsection{Aplikasi Halaman Login}

Halaman Login ini berfungsi untuk masuk ke halaman berikutnya, yaitu dengan menginput username dan password dengan benar maka akan masuk ke halaman Admin. Sehinggai user atau pengguna dapat melihat menu input dan output pada Gambar Login ini dapat dilihat pada Gambar 7.

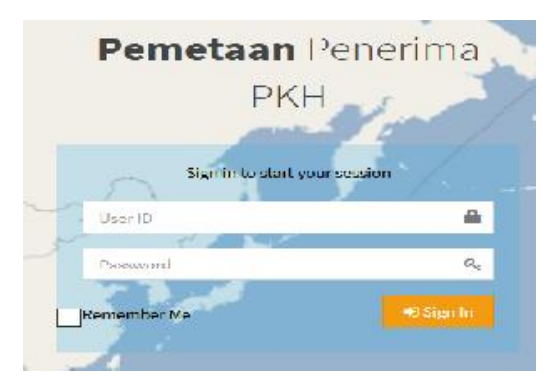

Gambar 7. Halaman login

\subsection{Dashboard Admin}

Dashboard Admin merupakan pusat kontrol dari aplikasi pemetaan penerima PKH Desa Beurawe Kecamatan Kuta Alam Kota Banda Aceh. Di form ini admin bisa melihat, mengedit dan menghapus data yang sudah ada, seperti pada Gambar 8 Dashboard Admin. 


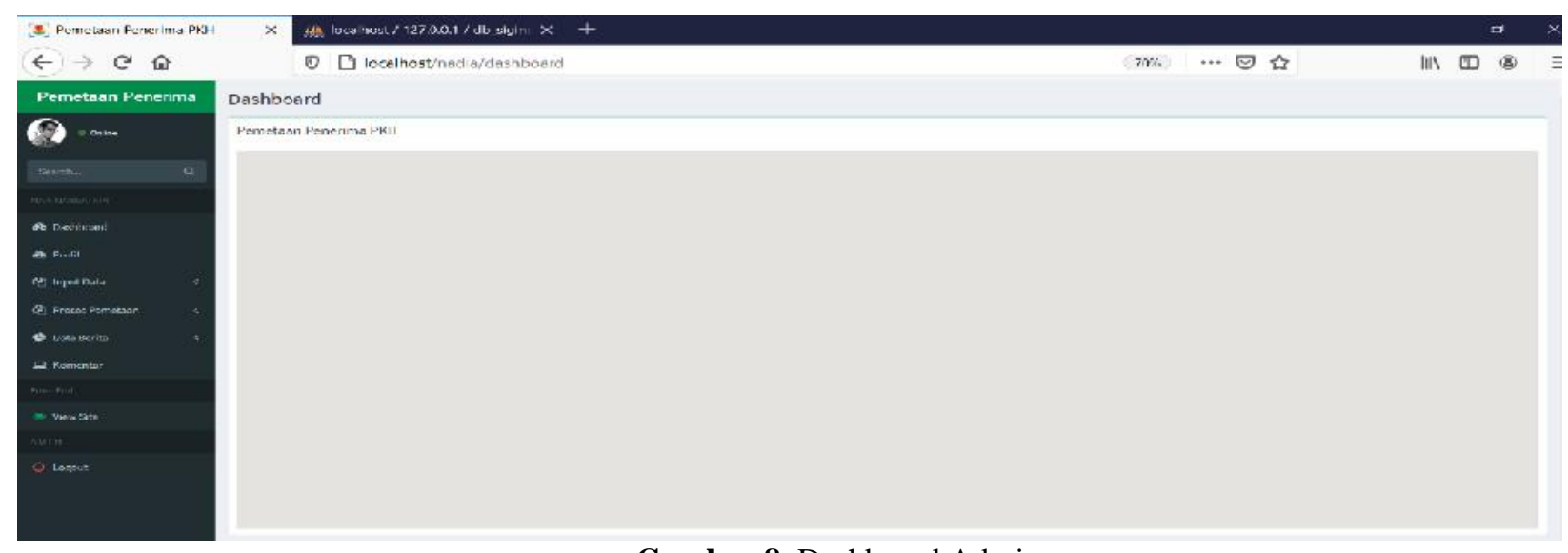

Gambar 8. Dashboard Admin

\subsection{Halaman User}

Halaman User pengguna Sistem Informasi Penerima PKH untuk menginput Menu dan sistem masyarakat desa beurawe penerima PKH ini dapat kita lihat pada Gambar 9 merupakan Halaman User Menu input Penerima PKH.

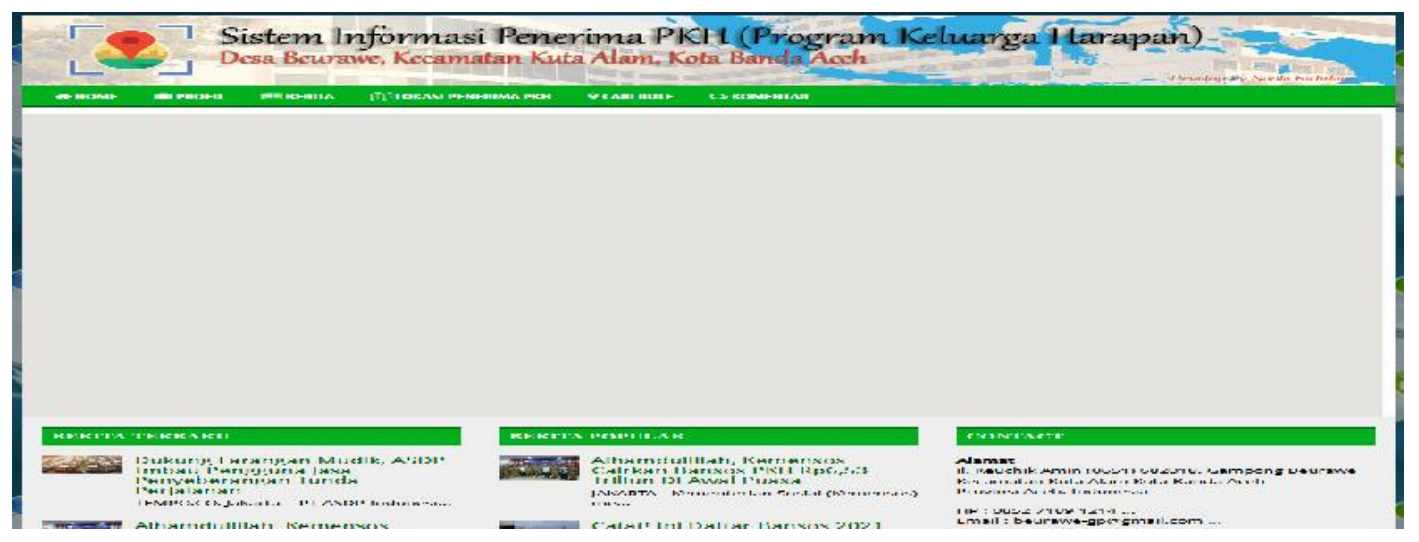

Gambar 9. Halaman User

\section{Kesimpulan}

Berdasarkan hasil pembahasan, penulis mengambil kesimpulan yaitu Aplikasi Sistem Informasi Pemetaan penerima PKH yang diusulkan dapat melihat sistem yang telah di buat secara cepat dan efisien sesuai dengan data yang ada. Aplikasi ini dapat memperoleh laporan keluarga penerima PKH tepat pada waktunya dan dengan adanya aplikasi Sistem Informasi Pemetaan penerima PKH pada Desa Beurawe Kecamatan Kuta Alam Kota Banda Aceh akan mempermudah mengakses data lokasi Pemetaan penerima PKH dengan cepat, akurat dan efisien. Aplikasi Sistem Informasi Pemetaan penerima PKH ini akan memudahkan pencarian data serta mengurangi hal yang selama ini memerlukan tenaga dan biaya yang besar.

\section{Daftar Pustaka}

[1] A. Darlianto and I. Permana, 2016 , "Sistem Informasi Pencatatan Surat Masuk," J. Rekayasa dan Manaj. Sist. Inf., vol. 2, no. 1, pp. 37-43.

[2] Baraja, Nu'man. 2017. "Algoritma Pemograman Dasar". Yogyakarta: Graha Ilmu.

[3] Gondodiyoto dan Hendarti. 2016, Sistem Informasi dan Teknologi, Edisi II. Yogyakarta: C.V Andi Offset.

[4] Hartono, Jogiyanto. 2016, Pengenalan Komputer. Yogyakarta: C.V Andi Offset.

[5] Jogiyanto. 2014, Sistem Teknologi Informasi, Edisi III. Yogyakarta: C.V Andi Offset.

[6] Jogiyanto. 2016, Sistem Teknologi Informasi, Edisi IV. Yogyakarta: C.V Andi Offset.

[7] Kursini. 2016, Konsep dan Aplikasi Sistem Pendukung Keputusan. Yogyakarta: C.V Andi Offset.

[8] Miswar, Dedy. 2013. Kartografi Tematik. Universitas Lampung : Bandar Lampung. 
[9] Nugroho, Deni. 2014. "Hyper Text Transfer Protocol (HTTP)". Semarang: CV. Nugraha Perkasa Media.

[10] O’Brien, James. 2016, Pengantar Sistem Informasi, Edisi 12. Jakarta: Salemba Empat.

[11] R., Saifullah. 2014. "Basis data MySQL, Bahasa dan Algoritma Bangun Basis Data". Jakarta: PT. Elex Media Komputindo.

[12] R. Afyenni, 2014, "Perancangan Data Flow Diagram untuk Sistem Informasi Sekolah (Studi Kasus Pada SMA Pembangunan Laboratorium UNP)," Teknoif, vol. 2, no. 1, pp. 35-39.

[13] Simarmata, Deja. 2016. "Pengolahan Web Server Berbasis Localhost Dalam Komunikasi Protokol". Surabaya: Wahana Komputer.

[14] Sariyono, Endro K. dan Muhammad Nursa'ban. 2010. Kartografi Dasar. Yogyakarta: Universitas Negeri Yogyakarta.

[15] Y. F. dan J. Waterkamp, 2017, "Jurnal Sistem Informasi (Journal of Information Systems DOI :http://dx.doi.org/10.21609/jsi.v13i2.545," Anal. Dan Perenc. Strateg. Sist. Dan Teknol. Inf. Menggunakan Balanc. Scorec. Pada Inst. Bisnis Dan Inform. K wik Kian Gie, vol. 13, pp. 103-109.

[16] Yulianto, T., Agus. 2016. "Interpretasi Pemograman PHP dan MYSQL". Jakarta: Salemba Empat Ramadhan, Saidi. 2014. "Pengenalan dan Panduan Lengkap Penggunaan Macromedia Dreamweaver". Jakarta: Erlangga. 